\title{
Free Trade and Employment in the ASEAN: From Theory to Empirical
}

\author{
Hui-Chin Lai \\ National Cheng Kung University, Tainan
}

\begin{abstract}
The issue of free trade and employment has been aconcerned for many countries for a long time. It seems that there exists a tradeoff between them. This paper looks back at the theories from the classical economics and discusses the role of free trade in economics. It also discusses the relationship between free trade and a nation's wealth, and the problems of free trade we face today. The theory is not challenged in the paper; however, the multi-functional state engaged within the market for full employment is included. The statistics and data of ASEAN are utilized to explain and examine the theory. A few ways of government intervention are introduced and regulations that are detrimental to employment are also discussed.
\end{abstract}

Keywords: ASEAN, employment, free trade, comparative advantages, the value of labor, national wealth, environmental law, labor law

\section{Introduction}

Free trade has become one of the most controversial topics discussed among economists, as it is one of the most critical policies in international economics since the classical era. Free trade has brought many of the contentious issues, for instance, industry offshoring, outflow of the technology, and stagnant wages. Offshoring brings about unemployment whereas outflow of the technology makes it more difficult for people to find jobs. The ramifications of these are actually all about unemployment.

In the market of classical economics, these problems have never occurred and have never been mentioned. In that case, in the market hundreds of years later today, how should we look upon these challenges? Are we going to revise the classical theory of economics?

To clarify these problems, this paper will focus on discussing the relationship between free trade and the economy, theories between free trade and employment, from the classical economics to today. The statistics of Association of Southeast Asian Nations (ASEAN) are utilized to reflect and examine the cruxes of the theory and the problems. And in the end, it will provide some policies and opinions on unemployment and how the government should intervene.

\section{Free Trade Theory}

The concept of free trade, as elaborated in theories from Adam Smith's (1776) absolute comparative advantage to David Ricardo's (1911) relative comparative advantage, is a self-adjusted market mechanism that allows workers to be better off due to trade with other countries. The conception of the theory that it is better

Hui-Chin Lai, Ph.D. student, Graduate Institute of Political Economy, National Cheng Kung University. 
for governments not to interfere in markets, including the labor market, so that they can find equilibrium on their own, is the principle that most economists believe in.

What makes free trade attractive is that it envisions great prospects, where two parties will gain as long as they are willing to exchange goods in which they have comparative advantages. Many countries have thus removed protection from their domestic industries and embraced the prospects of world trade. This is evidenced by a growing number of free trade agreements signed around the world.

The defense for free trade from protectionism can be seen from Adam Smith's (1776). The Wealth of Nations where he criticized mercantilism who urged the state to establish a restriction on trade.

In order to obtain this relative advantage in the colony trade, in order to execute the invidious and malignant project of excluding as much as possible other nations from any share in it, England, there are very probable reasons for believing, has not only sacrificed a part of the absolute advantage which she, as well as every other nation, might have derived from that trade, but has subjected herself both to an absolute and to a relative disadvantage in almost every other branch of trade. (Smith, 1776, p. 175)

David Ricardo (1911) supported Adam Smith's trade liberalism and expanded to propose that "under a system of perfectly free commerce, each country naturally devotes its capital and labor to such employments as are most beneficial to each. This pursuit of individual advantage is admirably connected with the universal good of the whole (p. 81)". It is evident that the classical economists are in favor of free trade. With their support, free trade has become an unbreakable conception where people talk about trade. It envisions the trading nations to pursue the prospect of being better off.

With the expansion of trade, however, it is an important issue to comprehend the role free trade plays in economic growth, and what is the connection between free trade and the national wealth.

It is clearly written that the foundation of economics in terms of the value of labor is that people are "useful for the necessaries and conveniences of life ${ }^{1 "}$. The usefulness for necessaries and conveniences of life can be explained into two tiers of meanings - the value of labor and the ability to consume and produce the necessaries and conveniences of life. A person's desire ${ }^{2}$ for the quality of necessaries and conveniences does not necessarily have to be produced on his own, he can sell necessaries and conveniences that he has but does not need and buy the ones he wants through the market.

It is important that the market participants are able to trade freely. The conception of free trade is correspondent to the pursuit of free exchange. Without a free phenomenon on trade, the economic activities will be restrained; the welfare of the people unable to expand and the market cannot function well. In the absence of free trade, the value of a person to be useful and the prospect of a better life cannot be shown. The conceptualization of free trade that renders workers to be better off is then impracticable. Therefore, it is understandable that classic economists advocate free trade and deem free trade as part of the theories that can build the wealth of a nation.

Free trade has facilitated the flow of trade and helped expand the size of economies. Since the beginning

\footnotetext{
1 The importance of the value of labor to the economics can been seen "Labor, therefore, is the real measure of the exchangeable value of all commodities" (Smith, 1776, p. 133). Also, David Ricard (1911) went along with Adam Smith's conception of value in his works such as chapter one, on value, The Principles of Political Economy and Taxation.

2 The desire is deemed to be a part of value of creating wealth. The text and example given to demonstrate this can be seen from "wealth and riches ... at one time as depending on exchangeable value and at another as constituted by the abundance of the objects of man's desire" (Maitland, 1804, p. 146).
} 
of the industrial revolution, international trade has progressively expanded to the extent that it is now capable of impacting the world economy.

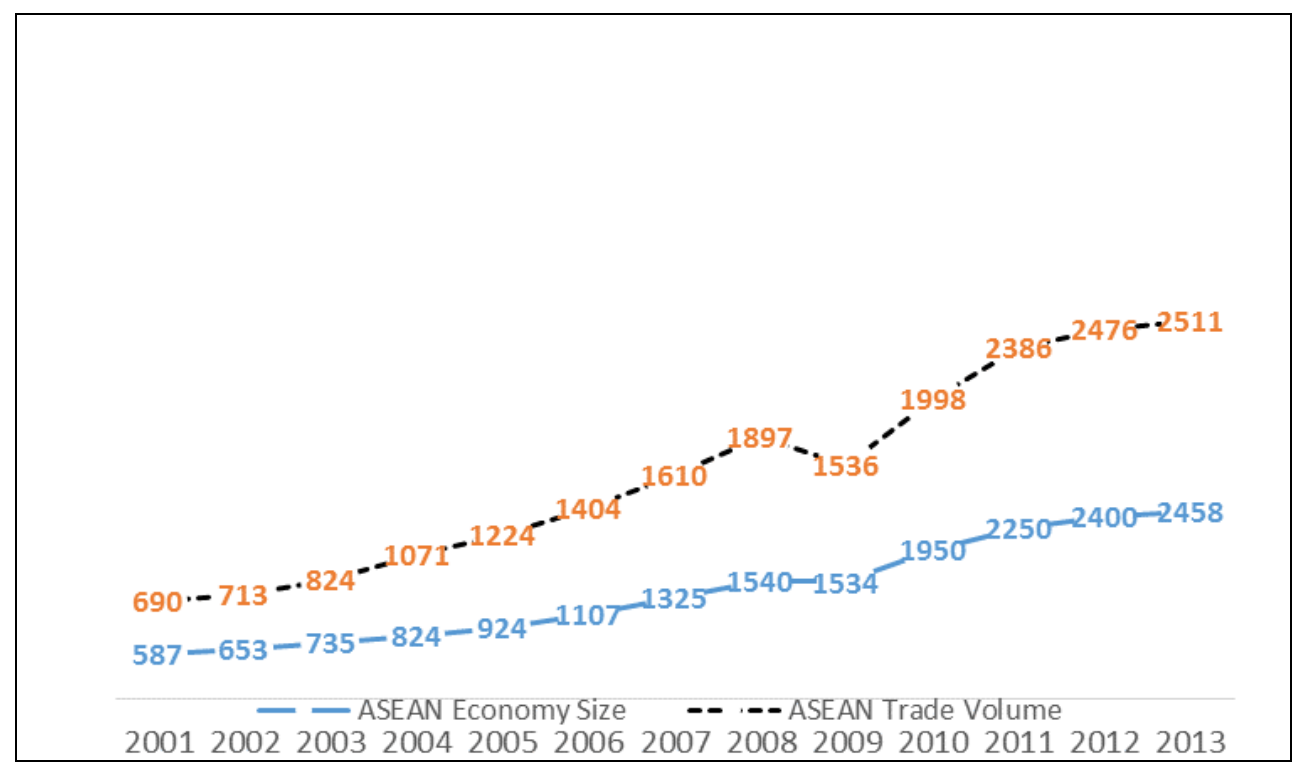

Figure 1. ASEAN economy size and trade volume (USD Billion).

Source: World Bank, retrieved from http://www.wits.worldbank.org; ASEAN (Association of South East Asia Nations), retrievd from http://www.asean.org; India $\mathrm{ASEAN}^{3}$, retrievd from http://www. Indiaasean.org

In ASEAN, intra and extra trades of ASEAN are not only allowed to grow beyond existing limits in terms of the economy, but also increase outputs and create mutual benefits for those involved in trade. From Figure 1, we can see that the scale of internal and external trading of ASEAN is positively proportioned with the expansion of the economy. The trading volume of ASEAN, has grown constantly from 690 billion USD in 2001 to 2,511 billion USD in 2013. Ten countries have expanded 1,821 billion USD of trading volume in 13 years. The entire GDP of ASEAN has increased by 1,871 billion USD likewise, from 587 billion in 2001 to 2,458 billion in 2013. It can be seen that the economy size and trading volume almost raise concurrently. These data have proven the closer relationship between free trade and the growth of nations' wealth. .

However, free trade does not work without problems. Businesses move offshore, people lose jobs and lose skills as well. As a result, some scholars have proclaimed protectionism. ${ }^{4}$ Many conveyed their worries and believed in the use of more protective methods to restrict free trade where unemployment can be preventive. It is worth discussing the cause and effect of the problems between free trade and employment.

\section{Problems of Free Trade}

As history progresses, the market has become more complicated with time and unemployment appears cyclically. In the past, people could still perform work like hunting and farming to support themselves. However, with modernization in countries, the environment of people who could find a way to perform work

\footnotetext{
3 The economy size of ASEAN is calculated by adding 10 country's GDP to the sum. The 10 countries are Brunei, Cambodia, Indonesia, Lao, Malaysia, Myanmar, Philippines, Singapore, Thailand and Vietnam. It is sourced from http://www.wits.worldbank.org. The trade volume data is obtained from two sources including http://www.asean.org and http://www. Indiaasean.org

4 The main thing which caused so much liberal opinion in England to lose its faith in free trade was the helplessness of older liberalism in face of massive unemployment, and the possibility of using import restrictions as an active program to fight unemployment (Hicks, 1959, p. 48).
} 
and earn for basic needs has been limited. Those in the city without a job are not able to provide for themselves. Unemployment occurs. People who have lost their jobs and could not find a way as the old days did for hunting and fishing can hardly fulfill their desire for necessaries and conveniences. Those who want to find jobs fail to do so, they are being unemployed as a consequence.

An odd phenomena is created, that is, high economic-growth countries with high rates of unemployment. According to the macroeconomics data of World Bank and IMF for the eight years from 2005 to 2013, countries such as Indonesia and Philippines have experienced high rates of economic growth, but they also have a high percentage of unemployed.

Table 1

Economic Growth and Unemployment Rate in Indonesia

\begin{tabular}{lccllllllll}
\hline & 2005 & 2006 & 2007 & 2008 & 2009 & 2010 & 2011 & 2012 & 2013 \\
\hline Economic Growth & 5.7 & 5.5 & 6.3 & 6 & 4.6 & 6.2 & 6.2 & 6 & 5.6 \\
Unemployment Rate & 11.24 & 10.28 & 9.11 & 8.39 & 7.87 & 7.14 & 6.56 & 6.14 & 6.25 \\
\hline
\end{tabular}

Source: World Bank ; IMF World Economic Outlook.

Table 2

Economic Growth and Unemployment Rate in Philippine

\begin{tabular}{lllllllllll}
\hline & 2005 & 2006 & 2007 & 2008 & 2009 & 2010 & 2011 & 2012 & 2013 \\
\hline Economic Growth & 4.8 & 5.2 & 6.6 & 4.2 & 1.1 & 7.6 & 3.7 & 6.8 & 7.2 \\
Unemployment Rate & 11.35 & 7.95 & 7.33 & 7.4 & 7.48 & 7.33 & 7.03 & 6.98 & 7.06 \\
\hline
\end{tabular}

Source: World Bank ; IMF World Economic Outlook.

It is possible for countries that are developing to have both high economic growth rate and high unemployment rate. When the inhabitants of ordinary environments have been degraded by the economic development, the likelihood of people living though fish, hunting or ordinary farming has been diminished. People have lost their old lifestyle but are unable to fit into the new lifestyle of modernisation.

As we all know, unemployment creates an insufficiency in demand and goods cannot be supported without purchasing power. There is a limit to humans. It is not just a commodity - if it is not sold today, it can be left there longer to wait for a right price or the buyer to show up to be exchanged. We get sick, skills learned will fade, we need to take care of the next generation, and we also need to be taken care of when we become old. It is impossible for humans to wait for the day to be hired again without having any impact on their functionality and practicality. When people lose their jobs, they are losing their income to support the purchasing power. When output from those employed loses the support of purchasing power, the value of the output will become lower, and thus have an influence on the income of people who have jobs. In this serious condition, it will even lead to unemployment for the previously employed. All of these are the reasons of economic recession. As a result, if Indonesia and Philippines could lower their rate of unemployment; the unemployed is "employed" to contribute their value of labor towards their living, the two countries will certainly perform better on the nation's wealth.

Another key reason why unemployment arises is that wages are fixed to a certain degree. Richard Brecher (1974) used econometric models to describe the characteristics of wages in his study. Much of the standard (flexible-wage) theory needs revision when the real wage is constrained by a floo (Brecher, 1974, p. 114). The rigidity of wages keeps the labor market from finding equilibrium in a short time. In a sense, the level of 
wage rigidity in cities is likely to be higher than in the country side, mostly as a result of the higher cost of living and the alternative of living without being employed is low.

There is no requisition of minimum wages in some countries, so there should not be rigidity in wages theoretically; nonetheless, still something is worth thinking that gives rise to wages rigidity but not by virtue of regulations; these are social norms. We can ascertain the apprehension in many classical economic works, namely if a person is capable of working and bringing home the bacon in a society providing for their family or society, it is a comparable term. For whether we obtain recognition from our behaviors or not, we often judge it by the point of view of others (Smith, 1759). So people will not easily accept works and wages that are far deviated from the social norms when they view their positions and wages from others' perspective. Geographical factors might also influences the degree of social norms. People working in the farm or countryside are likely less engaged with other people, and social norms seem to appear more apparent in countries or areas that are more developed.

It is invisible but present that the social norms have brought about the wages rigidity and the negative impact on employment. Under Jon Elster's (1989) observation, social norms are highly rigid, regardless of extenuating circumstances or better options are on the table (Elsrer, 1989, p. 99). When people are making decisions, it will be easier if they keep to the social norms; also, there is no need for them to worry about the disapprovals (Elster, 1989, p. 104 ). These notions are much alike the Adam Smith's (1759/2011) perspectives in the Theory of Moral Sentiments, people hope that they themselves are being beloved but are afraid of being disliked (Smith, 1759/2011). Nevertheless, Social norms could be ubiquitous and be a group behavior. The insensitivity will affect the values behind demands and supplies (Maitland, 1804, p. 146), making it a disadvantage for prices and wages to find equilibrium in the market. This further influences the job market and causes unemployment.

There are a lot of benefits if we view free trade from the point of an economy; as a matter of fact, there are also many problems. From the discussion above, we can see that these problems are rooted from employment. In that case, how should we treat these problems in terms of a nation's wealth? Which one is more important, free trade or full employment?

\section{The Importance and Implementation of Full Employment}

When full employment is achieved, people's usefulness towards necessaries and conveniences of life could be maximized under comparative advantages. The major problem of unemployment is that people are fundamentally different from goods. The labor conditions can change such as age, health, skills and relationships. People cannot be stored away for a long time like goods and perform unchanged when taken out of storage. Thus, nations should not allow unemployment to happen because that would let the people's skills deteriorate and the aggregate value of labor to go down. Without the support of unemployed people, purchasing power is discounted, the momentum of economic activities including trading gradually slows down, and the economic growth becomes blurred. As far as the reasoning goes, this highlights once again that the premise that people are better off with free trade, is constructed on the necessity of full employment.

Hence, the government should return to prioritizing full employment and developing the value of labor in order to walk down a path of long-term prosperity. Countries should be cautious about pursuing free trade before reaching full employment. Even if countries sign a free trade agreement with other countries, a withdrawal or fallback mechanism should be prepared so that unemployment problems are prioritized over free 
trade. There are many countries that don't necessarily consider how they can fulfill the conditions of full employment. If a government is setting policies and allowing free trade to sacrifice employment and the value of labor, it is like placing the cart before the horse is harnessed.

There are a lot of theoretical methods for the government to become involved in unemployment. For example, in Keynesian methods (Keynes, 1936) post-World War I, one of the notions was to expand government spending to support employment. The problem is that the labor market is somewhat inflexible, like the rigidity of wages and social norms. The market somehow is not as efficient as it should be; it is full of the characteristics of humans. The social conditions keep obstructing the market from finding equilibrium. So if a government is unable to understand differences in terms of geography, history, culture and its comparative advantages, then a simple expansion of spending could eventually lead to waste and inefficiency.

\section{Comparative Advantages and Diversity}

It is not that easy for a government to intervene in a country's economy. As mentioned above, it does not mean that once the government commences investing that it will turn out to have a positive effect on employment. If the government cannot let people put their skills into good use but merely have job opportunities, it will turn out to be inefficient and wasted.

Table 3

Top Products Exports by Countries in ASEAN

\begin{tabular}{|l|l|l|l|}
\hline Country & \multicolumn{3}{|c|}{ Top products exports } \\
\hline Brunei & Natural gas, liquefied & Petroleum oils, crude & Methanol “methyl alcohol” \\
\hline Cambodia & Postage, stamps & Clothes & Jerseys, pullovers, cardigans \\
\hline Indonesia & Coal & Crude palm oil & Palm oil and its fractions \\
\hline Lao & Refined copper & Copper Ore & Wood \\
\hline Malaysia & Natural gas, liquefied & Electronic related & Petroleum oils, crude \\
\hline Myanmar & Natural gas in gaseous state & Wood & Precious stone \\
\hline Philippines & Automatic related & Electronic related & Builders'joinery and carpentry \\
\hline Singapore & Electronic related & Oil refinery & Parts of aeroplanes or helicopters \\
\hline Thailand & Automatic related & Oil refinery & Motor vehicles \\
\hline Vietnam & Oil refinery & Coffee & Footwear \\
\hline
\end{tabular}

Source: World Bank 5 .

From where should the government step in and handle with the unemployment, here are some recommendations. One is maintaining the comparative advantages, and the other is increasing the comparative advantages. The following Table 3 shows the main export commodities of the ASEAN countries. We can know the comparative advantages of a countrythrough its main export. It can be seen that the ASEAN has developed a wide range of specialisations on export. The stimulation from current comparative advantages and the development of more comparative advantages might be a more efficient way than the discretionary investment.

Further, a country's main export does not only show the strength of the productions, but deeper messages are hidden behind, such as a continuous improvement of the society. The theory deducted from above is that the purpose of the economy is to make people in the economies be better off and be satisfied with the necessaries and conveniences of life, the value of labor enriched and as well the national wealth. When the economy grows

\footnotetext{
5 Retrieved from http://wits.worldbank.org/
} 
to a certain extent, people will no longer pursue to only keep the basic needs but will progress to have better lives, for instance, cultural identity, collective identity and better infrastructures; things like better education, culture preservation and better living environments may become part of people's necessaries and conveniences of lives. Being part of it is being part of the economy, part of labor value and part of the comparative advantages.

The above, is to argue and discuss how and why the government should intervene the market when unemployment occurs under free trade. The following is, in contrast, to dissert the regulations that have resulted in unemployment.

\section{Regulations and Employment}

The regulations from a government may vary which may influence a nation's comparative advantages. The government does not play any role in the free trade model, in which the market adjusts itself. Assumed that two countries A and B both produce clothes and wine. A is comparatively advantaged in cloth production, and wine production is to $\mathrm{B}$. The government of $\mathrm{A}$ announces a new law to regulate the working hours to 45 hours per week and B with 30 hours a week. As a result, the cloth producers of B country, in order to maintain its export strength, will require an increase in capital for more effective production such as procuring machines. Capital and machines are all exchanged by the value of labor. Therefore, the comparative advantages are in reality changed to be less. The capital investments may be too heavy for some producers. If they cannot survive, unemployment will occur.

Another example is that the employment might be affected due to the variance of environmental regulations. Assuming two countries $\mathrm{AB}$ adopt two pollution standards upon manufacturing. One is stricter and another is looser. And the relocation cost is not costly. The manufacturers of A might move to B for the enjoyment of lower expenditure on pollution. The result of this is not because the workers are not comparatively advantaged. Nevertheless, it turns out that workers of A will suffer from unemployment.

From another perspective, the relocation of businesses that have resulted from different environmental standards does not reduce pollution. When an enterprise moves from one country to another for lower environmental standards, it usually means that it does not take pollution seriously. Consequently, the total pollution might remain the same even when a firm moves from one place to another.

The free trade theory takes the idea that both countries can be benefited from trading as a starting point. Hence, if the regulations between trading countries are different, the real comparative advantages cannot be manifested and worked upon. Then, the degree of benefits from trading will decrease. In the case of the environmental standards, it is not a favorable cooperation to pollute trading countries due to the variance of regulations; it is against the principal of reciprocity and that is the spirit of free trade. Therefore, it is important for countries that adopt free trade to help each other and work together.

\section{Conclusions}

The theory that has been developed from classical economists is not challenged; free trade and full employment are deemed to be both sides of one. The part that has been challenged is the adaption of employment in the environment. Along with the economic development, the equilibrium of reaching full employment has become increasingly difficult. Reasons that dysfunction the market may vary such as wages rigidity and social norms. Since the market cannot adjust itself easily, governments should intervene to help the 
unemployed achieve full employment.

This paper puts forward a few ways including maintaining comparative advantages and enhancing comparative advantages from the perspectives of the main export in each country, which engender the government intervention more effective and less wasted. The unemployment that is resulted from regulation is also maintained. The benefits of free trade may be doomed and deteriorated because of the environment degradation and the discernments of regulations.

The environment of today's world has become increasingly complicated when compared to the old days. The complexity and diversity is not averse to a nation's economics, as argued and conceptualized in the article, as long as full employment is reached. Only when under the full employment, the reciprocal and mutual benefits of free trade will not be distorted and can be achieved through the maximisation of comparative advantages, which is the value of labor, of trading nations.

\section{References}

Brecher, R. A. (1974) . Minimum wage rates and the pure theory of international trade. The Quarterly Journal of Economics, $88(1), 98-116$.

Elster, J. (1989) . Social norms and economic theory. The Journal of Economic Perspectives, 3(4), 99-117.

Hicks, J. R. (1959). Essays in world economics. Oxford: Clarendon.

Keynes, J. M. (1936). The general theory of employment interest and money. New York: Prometheus Books.

Maitland, J. (1804). An inquiry into the nature and origin of public wealth, and into the means and causes of its increase. Edinburgh: Kessinger Publishing.

Ricardo, D. (1911). The principle of political economy and taxation. New York: Dover Publications, Inc..

Smith, A. (1759/2011). The theory of moral sentiments. Gutenberg Publishers.

Smith, A. (1776). The wealth of nations. London: Pearson. 